\author{
Case Study
}

www.ijrap.net

(ISSN Online:2229-3566, ISSN Print:2277-4343)

\title{
AYURVEDIC MANAGEMENT OF LOW BACK PAIN WITH MODIFIED ABHYANGA: A CASE STUDY
}

Resmi Babu K ${ }^{1 *}$, Smitha ${ }^{2}$

${ }^{1}$ PG Scholar, Department of Panchakarma, MVR Ayurveda Medical College, Kannur, Kerala, India

${ }^{2}$ Guide and HOD, Department of Panchakarma, MVR Ayurveda Medical College, Kannur, Kerala, India

Received on: 18/10/21 Accepted on: 30/11/21

\author{
*Corresponding author \\ E-mail: resmibabu101@gmail.com
}

DOI: $10.7897 / 2277-4343.1206159$

\begin{abstract}
Low back pain is one of the widespread health problems and the leading cause of activity limitation and work absence worldwide. Among the types of low back pain, low back pain due to mechanical causes is more common. Abhyanga is an effective treatment for low back pain, which can be done as an OPD level treatment without causing much financial burden. Though it is a widely practised procedure, we did not explore its possibilities properly. Abhyanga can be modified by incorporating other massage techniques like Swedish massage for better application. Cupping is a variety of tapotement massage techniques of a Swedish massage. Abhyanga performed along with the cupping massage techniques is very effective in managing low back pain. A 45year old lady patient came to OPD complaining of low back pain. On examination, stooping posture during her work hours was concluded as the reason for the pain. She was treated with modified Abhyanga with moorchita tilataila for seven days. The procedure duration was 20 minutes. Treatment was found to be effective after treatment and after follow up as her symptoms wholly vanished.
\end{abstract}

Keywords: Low Back Pain, Abhyangam, Cupping (Tapotement) massage technique

\section{INTRODUCTION}

Abhyanga means Taila Mardana ${ }^{1}$ which is a type of Bahyasneha It is described as a daily regimen in Ayurvedic classics ${ }^{2}$. Application of oil to the skin followed by a massage in specific directions is well known by Abhyanga in Ayurveda ${ }^{3}$. Abhyanga mitigates Vata, promotes strength, sleep and growth. It is useful in Dagdha, Bhagna, Kshata, Ruja, Klama, Srama and Jara ${ }^{4}$. Abhyanga is done in 7 positions: sitting, supine, left lateral, supine, right lateral, supine, and sitting. A prone position is also recommended. Abhyanga is an effective and easy treatment that can be done at the OPD level as Sarvanga and Ekanga. Generally, Abhyanga is performed as linear massage except in the joints and abdomen, where circular movement is suggested. Modification of abhyanga can be done according to the disease and the patient. Here, abhyanga is modified by incorporating a cupping massage to better pain management. Cupping is one of the Tapotement massage techniques which comes under Swedish massage ${ }^{5}$. Swedish massage techniques apply deeper pressure than other massages and help loosen and relax the muscles. The tapotement techniques have a hyperemic effect on the skin. They also stimulate the nerve endings, which results in tiny muscular contraction and an overall increased tone ${ }^{6}$.

Back pain is one of the most common causes of disability and high healthcare expenses globally. It affects patients of all ages and backgrounds ${ }^{7}$. Mechanical pain is the most common type among back pains, accounting for more than $90 \%$ of back pain episodes. It usually affects patients aged 20-55 years and is of acute onset. The onset is often associated with lifting or bending and is generally relieved by rest. It is usually confined to the lumbosacral region, buttock, or thigh, and does not radiate beyond the knee. The examination may reveal an asymmetric local paraspinal muscle spasm and tenderness, and there may be painful restriction of some but not all movements ${ }^{8}$.

\section{CASE STUDY}

A 45-year-old female patient who complained of low back pain for two weeks came at OPD of MVRAMC, Kannur, Kerala, India. The patient has been an Ayurveda therapist for more than 20 years. She previously experienced occasional low back pain when there is much workload, and it subsides after applying oil and Kizhi. She also consulted an Allopathic practitioner and took Xray and blood tests, and the findings were normal. After a break, she again started low back pain associated with stiffness on rejoining the occupation. She also experienced difficulty attaining an upright position after a prolonged stooping posture.

\section{Examination}

Inspection: no redness or swelling, the normal curvature of the spine

Palpation: tenderness not elicited over the spinal region and slight tenderness over the paraspinal region

Range of movement: all movements were possible, but the patient had pain during lumbar flexion and extension

Special tests: The SLR test was negative

\section{METHODOLOGY}

Plan of treatment: modified abhyanga with Moorchita Tila Taila for seven days.

\section{Poorva karma}

Sambhara Sangraha: it includes the collection of medicines, steel vessels,

measuring jar, cotton towel and the stove. Murchita Tila Taila for the procedure

\section{Preparation of the patient}

Consent was obtained from the patient. The patient was asked to satisfy her natural urges. Vitals were checked. The patient was 
made to lie comfortably in a prone position and asked to uncover the low back region. A small rolled-up towel was placed under the forehead of the patient. Oil was made warm by the double boiling method and smeared on the low back region.

\section{Pradhanakarma}

Warm Taila was applied on the lower back region, and Abhyanga was performed in the cupping maneuver of tapotement massage technique. The whole palmar aspect of the hand was made into a 'cup' shape by slightly flexing the fingers. The hand was loosely held in this form and made to strike the patient's body via a loose rhythmic action and raised again rapidly. The palmar aspect of the hand does not contact the patient, and this cup shape makes a hollow space that may give rise to a distinctive sound. There was no bending of the wrist; the bending takes place at the elbow, and the forearm is lowered as the hand was brought down. Cupping starts from the L4 region and moves downwards and is done simultaneously on both sides of the spine. Cupping is done with one hand after the other rhythmically with proper pressure. Caution is taken to avoid repeated stroking over the same area. The whole lumbosacral region was covered by alternating the strokes.

\section{Duration- 20 minutes}

\section{Pashchat Karma}

The area was wiped with a cotton cloth. The patient was asked to take complete rest for 15 minutes

\section{Assessment criteria}

Assessment of pain based WOMAC Index

\begin{tabular}{|c|c|c|c|}
\hline Assessment criteria & BT & AT & FU \\
\hline Pain & 6 & 0 & 0 \\
\hline Stiffness & 2 & 0 & 0 \\
\hline Difficulty & 39 & 1 & 0 \\
\hline
\end{tabular}

BT: Before Treatment, AT: After Treatment, FU: Follow Up

\section{RESULTS}

The assessment was done using the WOMAC index. The total score of pain before treatment was 6 . The score changed to 0 after treatment, and this score is retained after follow up. The score of stiffness also changed from 2 to 0 . The total score of difficulty was 39 before treatment, and it reduced to 1 after treatment and then to 0 after follow up.

\section{DISCUSSION}

Abhyanga is a generally practiced procedure in our OPD as well as IPD. But at the same time, it is the least explored treatment modality. Ayurvedic Acharyas gave the freedom to manipulate every treatment modality according to the patient and disease. Incorporating the Swedish massage techniques into the Ayurvedic Abhyanga procedure provides a wide range of applicability. Abhyanga is taila mardana, which applies oil followed by a massage with a certain pressure. Tapotement massage techniques provide more force and thus can be incorporated into Abhyanga. Abhyanga was done with a cupping massage technique (tapotement) in mechanical low back pain in the present study. The procedure was done locally over the low back region for 20 minutes. Moorchita Tila taila was used for Abhyanga. The area was wiped with a cotton cloth. The assessment was done based on the WOMAC index. Pain is completely relieved on the $5^{\text {th }}$ day itself. Lumbar flexion and extension were possible without pain on the $7^{\text {th }}$ day of treatment. Pain, stiffness, and difficulty were relieved entirely after treatment. The effect of treatment was retained after follow up. After follow up period, the patient felt more fit and comfortable for her occupation. This modified abhyanga was effective in reducing pain, stiffness, and difficulty.

\section{CONCLUSION}

After seven days of treatment, low back pain was relieved with modified Abhyanga using the cupping massage technique. Stiffness and difficulty were also relieved. The result of the therapy was sustained after the follow-up period. This modified form of Abhyanga was very effective in treating mechanical low back pain.

\section{REFERENCES}

1. Raja Radhakanthadeva Bahadurena, Shabdha Kalpadruma. Vol. 1, Delhi: Nag Publishers. P 78.

2. Vagbhata, Ashtangahrdayam with Sarvangasundara teeka of Arunadatta and Ayurvedarasayana teeka of Hemadri, Sutrasthana, chapter $2 / 8$, edited by Harisastri Paradakara Vaidya, Chaukhambha Orientalia, Varanasi, Reprint 2017; P 26.

3. Dr Shrinivasa Acharya, Panchakarma Illustrated, Delhi: Chaukhambha Sanskrit Pratishthan; 2015; P 102

4. Vridha Vagbhata, Ashtanga Sangraham with Sasilekha commentary of Indu, chapter 3/28, edited by Dr Shivaprasad Sharma, Chaukhamba Sanskrit Series Varanasi; Reprint 2006. P 20.

5. Ernst E. The safety of massage therapy. Rheumatology (Oxford).2003 Sep;42(9):1101-6. DOI: 10.1093/rheumatology/keg306. Epub 2003 May 30. PMID:12777645.

6. Mario- Paul Cassar, Elsevier, Handbook of clinical massage, A Complete Guide for Students and Professionals, $2^{\text {nd }}$ ed. Churchill Livingstone 2006. P 41

7. El Sayed M, Callahan AL. Mechanical Back Strain. [Updated 2021 Jan 30]. In: StatPearls [Internet]. Treasure Island (FL): StatPearls Publishing; 2021 Jan-. Available from: https://www.ncbi.nlm.nih.gov/books/NBK542314/

8. Nicholas A. Boon, Nicki R. Colledge, Brian R. Walker, Stuart H. Ralston, Davidson's Principles and Practice of Medicine 20th ed. Churchill Livingstone, Elsevier, 2006. P 1083.

\section{Cite this article as:}

Resmi Babu K and Smitha. Ayurvedic management of low back pain with modified abhyanga: A Case Study. Int. J. Res. Ayurveda Pharm. 2021;12(6):1-2 http://dx.doi.org/10.7897/ $\underline{2277-4343.1206159}$ 